\title{
Gold nanoparticles associated with temozolomide for glioblastoma Multiforme
}

\section{Treatment}

\author{
Nanopartículas de ouro associadas à temozolomida para tratamento de Glioblastoma Multiforme \\ Nanopartículas de oro asociadas con temozolomida para el tratamiento del Glioblastoma
}

\section{Multiforme}

\begin{abstract}
Malignant neoplasms represents a group of diseases that features, as a characteristic, the genetic differentiation of the original tissue, leading to the disordered growth of cells, invading normal tissues and organs. Among the most aggressive tumors, Glioblastoma Multiforme has a mortality rate around 95\% and survival's average of 15 months, even though all treatment available. Temozolomide (TMZ) is the chemotherapeutic drug so far tested and approved with the highest response in this tumor sub-type and must be associated to other treatments to achieve better results. Thus, the purpose of this work was to evaluate the performance of this therapeutic modality with gold nanoparticles (AuNPs) and also combined with radiotherapy. TMZ hydrolysis was characterized at different $\mathrm{pH}$ and the chemical changes on molecular structure was determined via Fourier Transform Infrared Spectroscopy (FT-IR). The treatment performance was verified in vitro test using TMZ, TMZ plus AuNPs and associated with radiotherapy. The TMZ concentrations were varied from 0 (control group) to $1000 \mu \mathrm{M}$, combined with AuNPs from 0 (control group) to $10^{10}$ nanoparticles per well. The results showed the drug is stable at $\mathrm{pH}$ values between 2 to 4 , but for $\mathrm{pH}$ values close to the physiological or basic medium, degradation is accentuated reaching a rate of $16 \% /$ hour. The changes on molecular structure of TMZ can be observed through the FT-IR spectra, where the release of oxygen in the structure has influence on $\mathrm{C}=\mathrm{O}$ group. The results of in vitro experiments showed that the highest poor results in the absence of ionizing irradiation. However, for experiments with $\mathrm{TMZ}$ and nanoparticles associated to radiotherapy, the performance of the treatment increased. In summary, the AuNPs showed important results under irradiation, revealing the same level of cytotoxicity for the highest TMZ concentration without irradiation. Also, the synergic effect between AuNPs and TMZ was observed under irradiation condition.
\end{abstract}

Keywords: Glioblastoma; Gold nanoparticles; Temozolomide; Radiotherapy.

\section{Resumo}

As neoplasias malignas representam um grupo de doenças que apresenta, como característica, a diferenciação genética do tecido original, levando ao crescimento desordenado das células, invadindo tecidos e órgãos normais. Dentre os tumores mais agressivos, o Glioblastoma Multiforme tem mortalidade em torno de $95 \%$ e sobrevida média de 15 meses, mesmo com todos os tratamentos disponíveis. A temozolomida (TMZ) é o quimioterápico até o momento testado e aprovado com maior resposta nesse subtipo tumoral e deve ser associado a outros tratamentos para obter melhores resultados. Assim, o objetivo deste trabalho foi avaliar o desempenho desta modalidade terapêutica com 
nanopartículas de ouro (AuNPs) e também combinada com a radioterapia. A hidrólise de TMZ foi caracterizada em diferentes $\mathrm{pH}$ e as alterações químicas na estrutura molecular foram determinadas por meio de Espectroscopia de Infravermelho com Transformada de Fourier (FT-IR). O desempenho do tratamento foi verificado em teste in vitro utilizando TMZ, TMZ mais AuNPs e associado à radioterapia. As concentrações de TMZ variaram de 0 (grupo de controle) a $1000 \mu \mathrm{M}$, combinadas com AuNPs de 0 (grupo de controle) a $10^{10}$ nanopartículas por poço. Os resultados mostraram que o fármaco é estável em valores de $\mathrm{pH}$ entre 2 a 4, mas para valores de pH próximos ao meio fisiológico ou básico, a degradação é acentuada atingindo uma taxa de 16\% / hora. As mudanças na estrutura molecular da TMZ podem ser observadas através dos espectros FT-IR, quando a liberação de oxigênio na estrutura influencia no grupo $\mathrm{C}=\mathrm{O}$. Os resultados dos experimentos in vitro mostraram que os piores resultados foram na ausência de irradiação ionizante. Porém, para experimentos com TMZ e nanopartículas associadas à radioterapia, o desempenho do tratamento aumentou. A Conclusão foi que as AuNPs apresentaram resultados importantes sob irradiação, revelando o mesmo nível de citotoxicidade para a maior concentração de TMZ sem irradiação. Além disso, o efeito sinérgico entre AuNPs e TMZ foi observado sob condição de irradiação.

Palavras-chave: Glioblastoma; Nanopartículas de ouro; Temozolomida; Radioterapia.

\section{Resumen}

Las neoplasias malignas representan un grupo de enfermedades que tiene como característica la diferenciación genética del tejido original, lo que lleva al crecimiento desordenado de las células, invadiendo tejidos y órganos normales. Entre los tumores más agresivos, el glioblastoma multiforme tiene una tasa de mortalidad de alrededor del 95\% y un promedio de supervivencia de 15 meses, a pesar de que todos los tratamientos están disponibles. La temozolomida (TMZ) es el fármaco quimioterapéutico probado y aprobado hasta ahora con mayor respuesta en este subtipo de tumor y debe asociarse a otros tratamientos para lograr mejores resultados. Así, el propósito de este trabajo fue evaluar el desempeño de esta modalidad terapéutica con nanopartículas de oro (AuNPs) y también combinado con radioterapia. Se caracterizó la hidrólisis de TMZ a diferentes pH y se determinaron los cambios químicos en la estructura molecular mediante Espectroscopía Infrarroja por Transformada de Fourier (FT-IR). El desempeño del tratamiento fue verificado in vitro usando TMZ, TMZ más AuNPs y asociado a radioterapia. Las concentraciones de TMZ se variaron de 0 (grupo de control) a $1000 \mu \mathrm{M}$, combinadas con AuNP de 0 (grupo de control) a 10 $0^{10}$ nanopartículas por pocillo. El fármaco es estable a valores de $\mathrm{pH}$ entre 2 a 4 , pero para valores de $\mathrm{pH}$ cercanos al medio fisiológico o básico, la degradación se acentúa alcanzando una tasa de 16\% / hora. Los cambios en la estructura molecular de TMZ se pueden observar a través de los espectros FT-IR, donde la liberación de oxígeno en la estructura tiene influencia sobre el grupo $\mathrm{C}=\mathrm{O}$. Los resultados de los experimentos in vitro mostraron que los peores resultados se produjeron en ausencia de irradiación ionizante. Sin embargo, para los experimentos con TMZ y nanopartículas asociadas a la radioterapia, el rendimiento del tratamiento aumentó. Las AuNP mostraron resultados importantes bajo irradiación, revelando el mismo nivel de citotoxicidad para la concentración más alta de TMZ sin irradiación. Además, el efecto sinérgico entre AuNP y TMZ se observó en condiciones de irradiación.

Palabras clave: Glioblastoma; Nanopartículas de oro; Temozolomida; Radioterapia.

\section{Introduction}

Malignant neoplasms represent a group of over 100 different diseases that features the genetic differentiation of the original tissue, leading to the disordered growth of cells, which invade normal tissues and organs. Cancer or malignant neoplasm is differentiated by the location of cell's origin, genetic and anatomopathological characteristics, cell differentiation, and potential for cell invasion and dissemination. The usual treatment for these diseases is classified as localized and systemic. The localized occurs through surgery and radiotherapy, while the systemic include chemotherapy and hormone therapy (Pouchieu et al., 2018).

Although there have been significant advances in these traditional therapeutic modalities, malignant neoplasms still represent a major challenge, especially considering the subtypes of greater aggressiveness and lethality, being the second largest cause of death worldwide, only surpassed by cardiovascular diseases. Among the Central Nervous System (CNS) tumors, the Glioblastoma (GBM) is the most aggressive and lethal, being the most prevalent with a mortality rate of about $95 \%$ and the average of survival are 15 months. (Ostrom et al., 2018; Pérez-Herrero et al., 2018; Sandes et al., 2020; Torre et al., 2012; Wen et al., 2016). Traditional treatment for GBM includes surgery, with maximum resection possible, followed by radiation therapy adjuvant to chemotherapy. Among the drugs, Temozolomide (TMZ) has showed the best result for GBM, 
with an acceptable safety profile and a moderate improvement in the quality of life in patients (Dib et al., 2020; Newlands et al., 1997).

Several studies are underway in the search for new therapies (Ostrom et al., 2015; Beht et al., 2021). Using metallic nanoparticles is also one possibility very explored in new studies, which include the development enhancers of the radiotherapy effect. These nanoparticles can be associated with several chemotherapeutic agents in search of better results in cancer treatments, and they can be used in target therapy, decreasing toxicity in normal tissues, increasing the drug's half-life, protecting the drug from degradation, renal clearance, and increasing the solubility, providing the possibility of dose reduction and, fewer side effect (Melo et al., 2020; Pérez-Herrero et al., 2018). In this study, TMZ, TMZ plus AuNPs and associated with radiotherapy will be analyzed.

\section{Methodology}

The scientific methodology was based on Koche (2011). The synthesis and characterization of Gold Nanoparticles (AuNPs) were prepared according to our previous work reported, which is a colloidal suspension of AuNPs with diameter of $20 \mathrm{~nm}$ and peak LSPR absorption at $\sim 523 \mathrm{~nm}$ (Vieira et al., 2017). The temozolomide, $\mathrm{C}_{6} \mathrm{H}_{6} \mathrm{~N}_{6} \mathrm{O}_{2}$ (Sigma-Aldrich), were diluted in ultra-pure water and $\mathrm{pH}$ was adjusted up to the desired value using $\mathrm{HCl}$ and $\mathrm{NaOH}$ solutions. The UV-Visible spectra of the samples were acquired by DS-11 spectrophotometer (DeNovix Inc., USA) in the spectral region 190-840 nm, resolution of $1 \mathrm{~nm}$ and optical path length $1 \mathrm{~mm} .2 \mu \mathrm{L}$ of each sample was deposited on the instrument pedestal for analysis. The FT-IR spectra were recorded in the region $3000 \mathrm{~cm}^{-1}$ to $400 \mathrm{~cm}^{-1}$ with $32 \mathrm{scans}$, resolution of $4 \mathrm{~cm}^{-1}$, using Fourier Transform Infrared (FT-IT) spectrophotometer Spectrum 400 (Perkin Elmer, USA) couplet to total reflectance (ATR) accessory. The crystal material in the ATR unit was a diamond disc as internal-reflection element and the penetration depth ranges between 0.1 and $2 \mu \mathrm{m}$, which depends on refractive index, incidence angle of the beam, and wavelength.

For in vitro tests, the Cells were cultivated in $25 \mathrm{~cm}^{2}$ tissue culture flasks at $37^{\circ} \mathrm{C}$ in a humidified atmosphere containing 5\% $\mathrm{CO}_{2} / 95 \%$ air. Human Glioblastoma Cells (M059J, cell bank, Rio de Janeiro, BCRJ) were cultured in a medium containing a 1:1 mixture of Dulbecco's Modified Eagle's Medium and Ham's F12 medium with 2.5 mM L-glutamine adjusted to contain $15 \mathrm{mM}$ HEPES, $0.5 \mathrm{mM}$ sodium pyruvate, and $1.2 \mathrm{~g} / \mathrm{L}$ sodium bicarbonate supplemented with $0.05 \mathrm{mM}$ nonessential amino acids and $10 \%$ fetal bovine serum. For viability tests, the cells $\left(10^{5}\right.$ cells) were seeded onto four 96 -well plates and allowed to attach for 24 hours. The AuNPs concentrations was 0 (control group), $10^{6}(\mathrm{~N} 1), 10^{8}(\mathrm{~N} 2), 10^{9}(\mathrm{~N} 3), 10^{10}(\mathrm{~N} 4)$, nanoparticles $/ \mathrm{ml}$, pure or associated with TMZ at concentrations of 0 (control group), $250 \mu \mathrm{M}, 500 \mu \mathrm{M}, 750 \mu \mathrm{M}$ e $1000 \mu \mathrm{M}$. For these experiments, a group was kept at dark environment and another was irradiated with a Electron Linear Accelerator Siemens of $6 \mathrm{MV}$, with a dose rate of $200 \mathrm{cGy} / \mathrm{min}$, applied dose of $200 \mathrm{cGy}$, with an SSD distance of $100 \mathrm{~cm}$ and a $1.0 \mathrm{~cm}$ bolus at Clínica RadioImage located at Hospital Frei Galvão in Guaratinguetá-SP. The trypan blue exclusion test was performed after 48 hours of cells irradiation.

\section{Results}

Figure 1 shows the UV-visible spectra of TMZ as a function of concentration and the linear regression analysis between concentration and absorbance at 330nm. The values of R-Square and Pearson evaluate the quality of the fitted model on the data and it achieved a good relation between the variables. 
Figure 1 - UV-Visible spectra of TMZ: a) function of concentration; b) correlation between concentration and absorbance at $330 \mathrm{~nm}$.
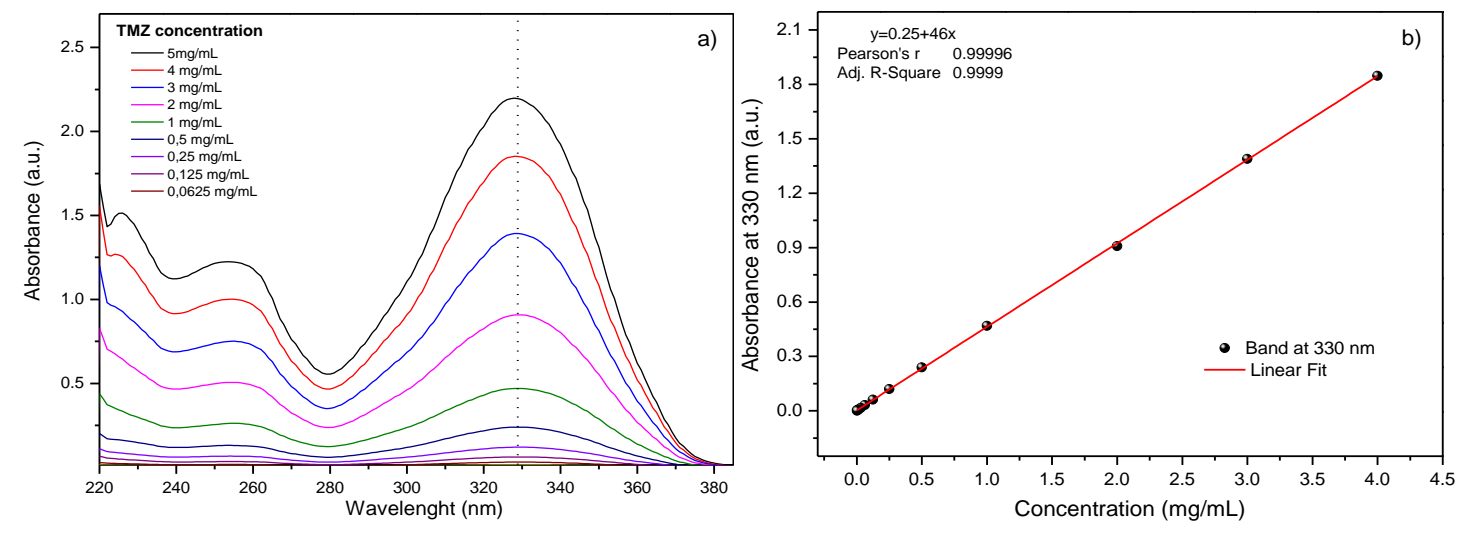

Source: Authors.

In this figure, it is important to observe the values of concentrations and the absorbance band at $330 \mathrm{~nm}$, which has a linear correlation through the equation $y=0.25+46 \mathrm{x}$ (Figure 1b). In addition, the integrity of TMZ structure diluted in an aqueous solution depends on $\mathrm{pH}$, as depicted in Figure 2. The first derivative of the data shows the chemical hydrolysis rate as a function of $\mathrm{pH}$, recording the lowest values up $\mathrm{pH} 4$, about $0.04 \% / \mathrm{h}$. The rate for $\mathrm{pH}$ values of 5,6 and 7 are $0.34 \% / \mathrm{h}, 0.74$ $\% / \mathrm{h}$ and $8.48 \% / \mathrm{h}$, respectively. However, the variation rates are increasing quickly for $\mathrm{pH}$ values higher than 7 , approximately $16 \% / \mathrm{h}$.

Figure 2 - Influences of time and solution $\mathrm{pH}$ on hydrolysis of the TMZ.

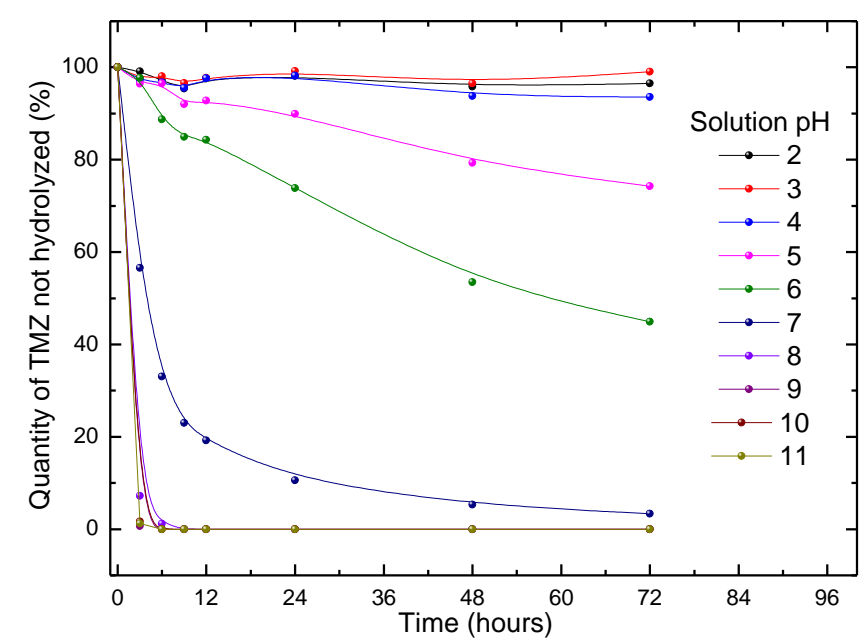

Source: Authors.

Indeed, the experimental time and solution $\mathrm{pH}$ have strong influence o TMZ hydrolysis that can be observed by the changes on curve slope. The changes in the molecular structure were reflected in the FT-IR spectra (Figure 3). The TMZ molecule is composed of 20 atoms, which have 54 normal modes of vibration at medium infrared. In the TMZ break down, there is a release of $\mathrm{CO}_{2}$, so the main structural changes are in the vibrational modes of oxygen interactions, which is associated with a band at $1758 \mathrm{~cm}^{-1}$ (Bhat et al., 2012). The spontaneous hydrolysis of TMZ will occur in a solution with a pH higher than 4 (see Figure 2), to form monomethyl triazene 5-(3-methyltriazen-1-yl)-imidazole-4-carboxamide (MTIC). MTIC then hydrolyzed to form 5-aminoimidazole-4-carboxamide that will convert into methylhydrazine (Chelliah et al., 2021). 
Figure 3 - FT-IR spectra of TMZ and TMZ hydrolyzed.

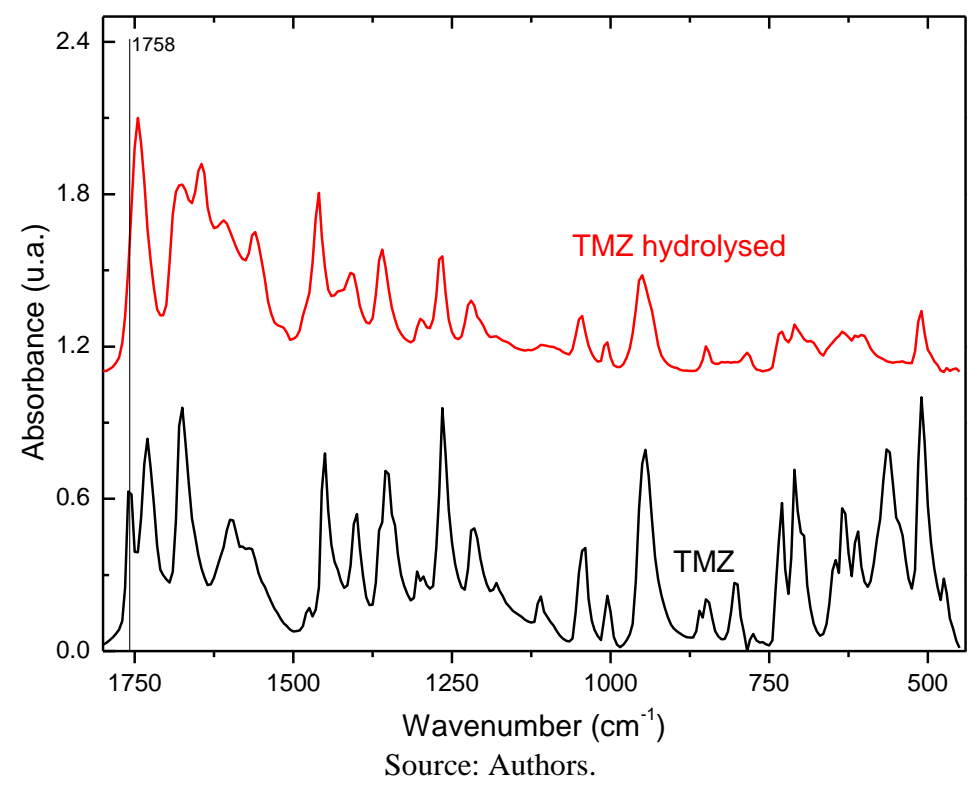

The comparison between IR spectra allows the identification of new vibrations modes after TMZ hydrolysis, which represents the changes on molecular structure as well as releasing of active radical for cancer treatment. Figure 4 shows the cell viability data for all experimental conditions, which was divided: a) for the group with any irradiation and b) irradiated by an Electron Linear Accelerator. The graphs combine the TMZ and AuNPs concentrations; the zero on X-axes represents the control groups without TMZ and the zero on graphs legend is the group without nanoparticles.

Figure 4 - Cells viabilities: a) without radiation; b) irradiated by Linear Accelerator.
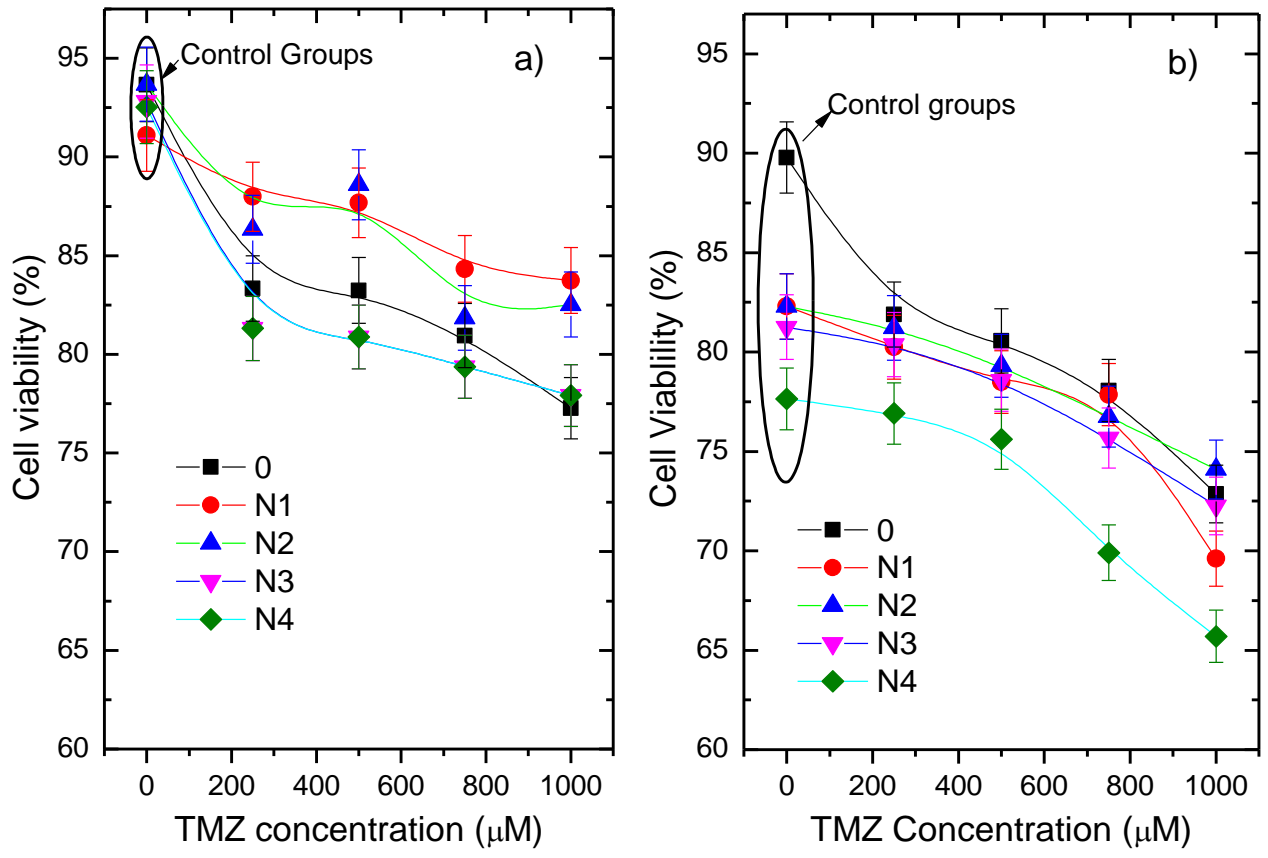

Source: Authors.

The cell viability is the most important results, allowing to compare the treatments and the influences of TMZ dose, AuNPs concentrations and the association of ionizing radiation. 


\section{Discussion}

GBM is a tumor subtype that still challenges researchers and health professionals, because of its high aggressiveness and the few clinical therapeutic possibilities available. One challenge is the difficulty related to drug access into the central nervous system and the adaptive resistance to anti-tumor drugs. For the radiation oncologists, the greatest challenge is to achieve the best radiation dose distribution in tumor tissue for greater local control, sparing the normal brain parenchyma. The treatments using ionizing radiation depend on interaction with the malignant tissue, which damages at an intracellular level, the cell components (direct action), and/or acts on the water molecule, generating free radicals that will indirectly damage the irradiated cell. X-ray photons interact with biological matter through interactions described by the Compton effect and/or Photoelectric effect (Mesbahi, 2010).

The current recommendations for treatment of patients with GBM is Temozolomide in good general condition (as assessed by the WHO-PS scale). In a studies of the EORTC-NCIC conducted by Stupp et al. (2009), 573 patients were randomized, a group received TMZ and concomitant postoperative radiotherapy for 6 weeks, followed by adjuvant TMZ, and a group received radiotherapy only. The chemoradiation had average survival of 14.6 months versus 12.1 months and a 2 -year survival of, respectively, $26.5 \%$ and $10.4 \%$, besides a 5 -year final survival of $10 \%$ versus $2 \%$ when compared to isolated radiation (Stupp et al., 2009). This drug is rapidly absorbed and its 100\% bioavailability occurs after 1 to 2 hours. The Fig ure 1 showed the linear relation TMZ band at $\sim 330 \mathrm{~nm}$ and concentration, which corresponds to a maximum absorbance of the electronic transition HOMO $\rightarrow$ LUMO (Bhat et al., 2012). To evaluate the stability of the TMZ diluted in aqueous medium with different pHs, the band at $\sim 330 \mathrm{~nm}$ was monitored, see Figure 2. The drug is stable at pH values of 2 to 4 , and no degradation was observed in the experimental time studied. While for $\mathrm{pH}$ values close to the physiological or basic medium, degradation is accentuated reaching a rate of $16 \%$ /hour. The $\mathrm{TMZ}$ hydrolysis break down the molecule ring and releases $\mathrm{CO}_{2}$ and generates MTIC. MTIC degrades into the methyldiazonium cation, which transfers the methyl group to DNA and the final degradation product, 5-amino-imidazol-4-carbozamide (AIC) is excreted by the kidneys. (Friedman et al., 2000).

The conversion of TMZ into MTIC occurs in an aqueous medium under physiological conditions, not requiring any enzymatic reaction, not requiring liver metabolism, making in vitro and in vivo studies easily reproducible. The changes on molecular structure of TMZ can be observed through the FT-IR spectra, where the release of oxygen in the structure has influence on $\mathrm{C}=\mathrm{O}$ group, which is highly polar and an intense absorption bands in the range 1700 to $1750 \mathrm{~cm}^{-1}(\mathrm{Bhat}$ et al., 2012).

The results of in vitro experiments showed that the highest concentration of TMZ lead to highest cell death, reaching $75 \%$ viability in the absence of ionizing irradiation. The AuNPs had no benefit of increasing cell's death even for higher concentrations, demonstrating the absence of a synergistic effect between AuNPs and TMZ without using irradiation. Indeed, the results using AuNPs seem to be worse, which is not desired and could be explained by gold surface affinity for the hydrolyzed TMZ radical.

Although the results of TMZ had low values of cytotoxicity, these results can be explained by the mechanism of TMZ action that is related to DNA damage and cell death due to apoptosis, which depends on the cell's cycle. In the literature, for in vivo experiments, an average of approximately 24 days is needed, justifying the cycles of 21 to 28 days between chemotherapies. In addition, both chemotherapy and radiotherapy are performed in cycles, since they have greater action during cell replication, but in this study, a single dose of the chemotherapy was performed, which may justify a maximum cell death of $75 \%$.

However, for experiments with TMZ and nanoparticles associated to radiotherapy, the performance of the treatment increased. The AuNPs with radiotherapy decreased cell viability at same level of the highest TMZ dose in the absence of ionizing irradiation. Indeed, recent studies have shown that gold nanoparticles increase tumor damage after radiation 
application. In this way, greater cell damage and tumor death would be possible with a lower dose of radiation, with a reduction in damage to normal cells around the tumor, which would increase the sensitivity and specificity of radiation treatment, with fewer adverse effects. (Hainfield et al., 2008). The increased response to radiotherapy with the association of TMZ and AuNPs represents the possibility of enhancing the treatment as well as a potential for reducing the dose of TMZ, which would represents a lower risk of toxicity and a potential reduction of treatment costs, in view of the reduced value of AuNPs, when compared to the cost of TMZ.

The association of gold nanoparticles with TMZ, was already promising in studies with glioma stem cells after irradiation, these cells being one of the responsible for the low effectiveness of the treatment, considering its resistance to the drug when used in isolation, but despite using a different method and different cell line, we obtained similar results. (Orza et al., 2013).

\section{Conclusions}

The AuNPs did not show synergic effect with TMZ without samples irradiation. Indeed, AuNPs seem to increase cell viability when associated with TMZ treatment. However, AuNPs showed important results under irradiation, revealing the same level of cytotoxicity for the highest TMZ concentration without irradiation. Also, the synergic effect between AuNPs and TMZ was observed under irradiation condition. The results of this work showed the viability for in vivo study.

\section{Acknowledgments}

The authors are grateful to FAPESP (Project 2017/07519-2) and CNPq (302944/2018-4)

\section{References}

Belter, A., Barciszewski, \& J. Barciszewska, A.-M (2020). Revealing the epigenetic effect of temozolomide on glioblastoma cell lines in therapeutic conditions. PLoS One. 15, e0229534

Bhat, S. A, \& Ahmad, S (2015). Quantum chemical calculations and analysis of FTIR, FT-Raman and UV-Vis spectra of temozolomide molecule J. Mol. Struct., 1099, 453-462.

Chelliah, S. S., Paul, E. A. L., Kamarudin, M. N. A. \&"Parhar, I (2021). Challenges and Perspectives of Standard Therapy and Drug Development in HighGrade Gliomas. Molecules, 26, 1169. https://doi.org/10.3390/molecules26041169

Dib, R. V., Gomes, A. M. T., Ramos, R. de S., França, L. C. M., \& Marques, S. C. (2020). Cancer and its social representations for cancer patients. Research, Society and Development, 9(9), e187997134. https://doi.org/10.33448/rsd-v9i9.7134

Friedman, H. S., Kerby T. \& Calvert H (2000). Temozolomide and treatment of malignant glioma. Clin Cancer Res. 6(7), $2585-2597$.

Hainfeld, J. F., Dilmanian, F. A., Slatkin, D. N. \& Smilowitz, H. M. (2008). Radiotherapy enhancement with gold nanoparticles. J Pharm Pharmacol. 60(8), 977-85. https://doi.org/10.1211/jpp.60.8.0005.

Koche, J. C. (2011). Fundamentos de metodologia científica. Vozes.

Melo, R. L. F., Souza, I. C. da C., Carvalho, A. J. R., Bezerra, E. M., \& Costa, R. F. da. (2020). Nanoparticles as biological tools: an exploratory review. Research, Society and Development, 9(7), e363974155. https://doi.org/10.33448/rsd-v9i7.4155

Mesbahi A. (2010). A review on gold nanoparticles radiosensitization effect in radiation therapy of cancer. Rep Pract Oncol Radiother. 15(6), 176-180. https://doi.org/10.1016/j.rpor.2010.09.001

Newlands E. S., Stevens M. F., Wedge, S. R., Wheelhouse, R. T. \& Brock, C. (1997). Temozolomide: a review of its discovery, chemical properties, preclinical development and clinical trials. Cancer Treat Rev. 23, 35-61. https://doi.org/10.1016/S0305-7372(97)90019-0

Orza, A., Soriţău, O., Tomuleasa, C., Olenic, L., Florea, A., Pana, O., Bratu, I., Pall, E., Florian, S., Casciano, D., \& Biris, A. S. (2013). Reversing chemoresistance of malignant glioma stem cells using gold nanoparticles. International journal of nanomedicine, 8, 689-702. https://doi.org/10.2147/IJN.S37481

Ostrom, Q. T., Gittleman, H., Fulop, J., Liu, M., Blanda, R., Kromer, C., Wolinsky, Y., Kruchko, C., \& Barnholtz-Sloan, J. S. (2015). CBTRUS Statistical Report: Primary Brain and Central Nervous System Tumors Diagnosed in the United States in 2008-2012. Neuro-oncology, 17 Suppl 4(Suppl 4), iv1-iv62. https://doi.org/10.1093/neuonc/nov189. 
Research, Society and Development, v. 10, n. 11, e146101119406, 2021

(CC BY 4.0) | ISSN 2525-3409 | DOI: http://dx.doi.org/10.33448/rsd-v10i11.19406

Ostrom, Q. T., Gittleman, H., Stetson, L., Virk, S., \& Barnholtz-Sloan, J. S. (2018). Epidemiology of Intracranial Gliomas. Progress in neurological surgery, 30, 1-11. https://doi.org/10.1159/000464374

Pérez-Herrero, E., \& Fernández-Medarde, A. (2015). Advanced targeted therapies in cancer: Drug nanocarriers, the future of chemotherapy. European journal of pharmaceutics and biopharmaceutics: official journal of Arbeitsgemeinschaft fur Pharmazeutische Verfahrenstechnik e.V, 93, 52-79. https://doi.org/10.1016/j.ejpb.2015.03.018

Pouchieu, C., Gruber, A., Berteaud, E., Ménégon, P., Monteil, P., Huchet A., Vignes, J-R., Vital, A., Loiseau, H. \& Baldi, I. (2018). Increasing incidence of central nervous system (CNS) tumors (2000-2012): findings from a population based registry in Gironde (France). BMC Cancer, 18, 1, 653 https://doi.org/10.1186/s12885-018-4545-9.

Sandes, V. dos A., Dantas, R. L., Porto, R. L. S., Reis, F. F. P., Sousa, D. S. de, Lima, S. O., Marcena, S. L. S., \& Reis, F. P. (2020). The occurrence of tumors of the central nervous system in the state of Sergipe from 2008 to 2017. Research, Society and Development, 9(11), e3439119673. https://doi.org/10.33448/rsd-v9i11.9673

Stupp, R., Hegi, M. E., Mason, W. P., van den Bent, M. J., Taphoorn, M. J., Janzer, R. C., Ludwin, S. K., Allgeier, A., Fisher, B., Belanger, K., Hau, P., Brandes, A. A., Gijtenbeek, J., Marosi, C., Vecht, C. J., Mokhtari, K., Wesseling, P., Villa, S., Eisenhauer, E., Gorlia, T., National Cancer Institute of Canada Clinical Trials Group (2009). Effects of radiotherapy with concomitant and adjuvant temozolomide versus radiotherapy alone on survival in glioblastoma in a randomised phase III study: 5-year analysis of the EORTC-NCIC trial. The Lancet. Oncology, 10(5), 459-466. https://doi.org/10.1016/S1470-2045(09)70025-

Behl, T., Sharma, A., Sharma, L., Sehgal, A., Singh, S., Sharma, N., Zengin, G., Bungau, S., Toma, M. M., Gitea, D., Babes, E. E., Judea Pusta, C. T. \& Bumbu, A. G. (2021). Current Perspective on the Natural Compounds and Drug Delivery Techniques in Glioblastoma Multiforme. Cancers, 13, 11, 2765. https://doi.org/10.3390/cancers13112765

Torre, L. A., Bray, F., Siegel, R. L., Ferlay, J., Lortet-Tieulent, J., \& Jemal A. (2015). Global cancer statistics, 2012. CA Cancer J Clin., 65(2), 87-108. https://doi.org/10.3322/caac.21262.

Vieira, L., Castilho, M. L., Ferreira, I., Ferreira-Strixino, J., Hewitt, K. C., \& Raniero, L. (2017). Synthesis and characterization of gold nanostructured Chorin e6 for Photodynamic Therapy. Photodiagnosis and photodynamic therapy, 18, 6-11. https://doi.org/10.1016/j.pdpdt.2016.12.012.

Wen, P. Y. \& Reardon, D. A. (2016). Neuro-oncology in 2015: Progress in glioma diagnosis, classification and treatment. Nat Rev Neurol 2016, 12, 69-70. https://doi.org/10.1038/nrneurol.2015.242 